\title{
ATTITUDES OF THE GENERAL PUBLIC AND HUNTERS TOWARDS WOLVES IN LATVIA; ITS PREDICTORS AND CHANGES OVER TIME
}

\author{
Agrita Žunna, Guna Bagrade, and Jānis Ozoliṇš \\ Latvian State Forest Research Institute "Silava", 111 Rĩgas Street, Salaspils, 2169, LATVIA \\ Corresponding author, agrita.zunna@ silava.Iv \\ Communicated by Tālis Gaitnieks
}

\begin{abstract}
A survey was carried out to determine the attitudes of the general public and of hunters towards wolves (Canis lupus) in Latvia. Today wildlife conservation depends on effective management practices; however, these are often influenced by public opinions and attitudes. Our aim was to understand the causes behind these attitudes and to compare our results with previous research done in Latvia. Questionnaires were distributed through schools and hunter organisations. The attitudes of both the general public and hunters were mostly neutral or positive. Older people and women were generally less positive. Respondents with less positive attitudes were more likely to say that wolf numbers in the country should be decreased. Significant associations between attitudes, beliefs of wolves causing damage and financial losses and what should be done with wolf numbers in Latvia were found. Three attitude predictors were established.
\end{abstract}

Key words: attitude predictors, Canis lupus, conservation, management.

\section{INTRODUCTION}

In the present day, wildlife conservation is as much a social issue as it is part of biological sciences. Species conservation depends on effective management practices; however, these are often influenced by public opinion. A person's attitude toward a species affects the acceptability of that species, and also the associated management actions (Bruskotter et al., 2009). In addition, different interest groups often have different opinions on how populations of wild animals should be managed. Concerning large carnivores, the most relevant interest groups are often hunters and farmers (Bath, 1987; Ericsson et al., 2004; Bath et al., 2008). These groups are only a small part of society and are not well represented in general population surveys (Ericsson and Heberlein, 2003). In order to carry out favourable and successful management practices and to ensure species conservation, knowledge of attitudes of the general public and relevant interest groups is necessary.

To understand human-wildlife relationships and to develop strategies that can reduce human-wildlife conflicts, there have been many studies on values, beliefs, attitudes, and behaviours associated with different species (Bath, 1987; Ful- ton et al., 1996; Zeiler et al., 1999; Ericsson and Heberlein, 2003; Manfredo, 2008; Glikmann et al., 2010; Sponarski et al., 2013). Attitudes are defined as a way of thinking or feeling about an object, for example, a wild species, and thus they determine whether a person will respond positively or negatively to a species (Fulton et al., 1996; Vaske and Donnelly, 1999; Manfredo, 2008). Predictors of attitudes can help determine the reasons why a species provokes certain feelings and can help to understand which management issues need to be addressed. For example, fear, impact on human life or property that species have and presence of animals are found to be some of the predictors influencing attitude (Røskaft et al., 2003; Bath et al., 2008; Frank et al., 2016).

The wolf (Canis lupus) is a protected species with an allowance for restricted use in Latvia. In previous centuries wolves were actively persecuted, however they were never eradicated from Latvia (Kawata et al., 2008; Ozolinš et al., 2017). Since Latvia's accession to the European Union and the implementation of the European Commission's Habitat Directive 92/43/EEC in 2004, restrictions on wolf hunting were introduced. The wolf conservation plan was first 
drafted in 2000 and signed by the minister of Environment Protection in 2003 (Ozoliņš and Andersone, 2002). To understand the feasibility of the required wolf conservation actions, a survey on public attitudes was performed for first time in Latvia (Andersone and Ozoliņš, 2004).

Attitudes towards wolves can range from strongly negative to strongly positive (Bath and Majic, 2000; Fritts et al., 2003). Farmers usually have most negative attitudes toward carnivores (Kellert, 1987; Bath and Buchanan, 1989; Williams et al., 2002). Similarly, hunters have more negative attitudes than non-hunters (Blanco et al., 1992; Zeiler et al., 1999; Røskaft et al., 2007; Sponarski et al., 2013), however this is not always the case (Bath and Majic, 2000; Ericsson and Heberlein, 2003). Older people tend to have a more negative attitude toward wolves, while younger generations usually are more positive (Ericsson and Heberlein, 2003; Røskaft et al., 2007). These social groups change over time in their quantitative representativeness within society as well as in their dominating opinions. Therefore, in cases when a species conservation plan requires updating, both at the international (Boitani et al., 2015) and country levels (Ozoliņš et al., 2017), a recent social survey is necessary.

The purpose of this survey was to determine the most recent attitudes, opinions and some of its predictors in the general public and a selection of hunters towards wolves, in order to predict the feasibility and focus points for implementation of planned management activities. Also, our aim was to compare the results with a previous study on public perception of large carnivores in Latvia (Andersone and Ozoliņš, 2004) that used a similar questionnaire and the same methodology.

\section{STUDY AREA}

Latvia occupies a $64580 \mathrm{~km}^{2}$ large territory along the eastern coast of the Baltic Sea. The density of the population in Latvia is 30 people per $\mathrm{km}^{2}$, and the number of inhabitants is 1.9 million. The majority of people live in cities or towns $(69 \%)$, with the rest being inhabitants of villages or farmsteads (Anonymous, 2017). About $1.8 \%$ of inhabitants hold hunting licenses (State Forest Service statistics). About 50\% of the region is covered by woodland, mostly mixed boreal forests, which are the main wolf habitat. Wolf numbers in the 1930s and 1960-1970s were low (below 50 individuals). In the 1990 s, the population increased up to 1000 individuals but intensive hunting brought it down. Since joining the EU in 2004, a closed season from the $1^{\text {st }}$ April till $15^{\text {th }}$ July and a hunting quota for each hunting season were introduced. At the time of the survey, the wolf population was estimated around 500-700 individuals before the start of hunting season. The population status is deemed favourable, but it is under intense hunting pressure. Population management is done in accordance with the wolf conservation plan. Today wolves are present over almost the entire country, with the exception of the mostly deforested central part of the country (Ozoliňš et al., 2017).
At the time of the previous public survey in the beginning of 2000s, wolf numbers were low, as was their prey base. Depredation on livestock was also rather low (less than fifty animals killed per year). Since then wolf numbers have grown and their wild prey is abundant. Since 2011, depredation cases have also increased, but are still rather low compared to other countries and it is not clear if depredation has really grown or just the number of reported cases. Hunting quotas have also increased during this time, approximately twofold (Ozoliņ̌s et al., 2017).

\section{MATERIALS AND METHODS}

The study was carried out in 2017. A written questionnaire was prepared and distributed to two respondent groups, defined as either the general public or hunters. The questionnaire design was based on a previous study done in Latvia (Andersone and Ozolinšs, 2004) and on a questionnaire used in the project "Large carnivores in northern landscapes: an interdisciplinary approach to their regional conservation" (2005). It contained 36 questions on attitudes, beliefs and knowledge toward wolves, as well as on the demographic information of respondents. For this analysis, 10 questions and demographic information was used (Table 1).

To sample the total population, questionnaires were distributed through randomly selected schools. The country was stratified into five geographic regions with the capital Riga including nearby towns as one of the regions. The number of questionnaires distributed per region was proportional to the number of inhabitants in the region. Questionnaires were given to a teacher who randomly chose a class in which to distribute them. Pupils were asked to take the questionnaires home and have them completed anonymously by one of the household members over 15 years of age according to the next birthday rule. 1000 questionnaires were distributed through 27 schools. In addition, an electronic version of the questionnaire was distributed among hunters using the help of two hunter organisations and a hunter's magazine. Responses of the hunter group (hereafter - HG) were analysed separately from the general public (hereafter - school group (SG)).

SPSS for Windows was used for statistical analyses. Spearman correlation, Kruskal Wallis, Cramer's V tests and nominal and ordinal regressions were used for analyses.

\section{RESULTS}

Sample characteristics. In total 595 questionnaires were returned from schools (giving a response rate of 59.5\%). Questionnaires returned by region were: Rīga $-40 \%$, West Latvia - 12\%, South Latvia - 14\%, North Latvia - 14\%, East Latvia - 20\%. From hunters 510 questionnaires were received.

Nearly $61 \%$ of respondents from the SG where females statistically significantly more than men in this group $\left(\chi^{2}=\right.$ $26.57,1 \mathrm{df}, p<0.001)$. The Latvian population is estimated 
Table 1. Items of the questionnaire used in the analyses

1. How many wolves do you think are found in Latvia today? *Less than $20 * 20-50 * 50-200 * 200-600 * 500-800$ *800-1000 *More than 1000

2. What do you think about the size of the population of wolves that we have in Latvia today?

*Too few *Enough *A lot *Do not know

3. What should be done with the number of wolves in Latvia? *Exterminate *Greatly reduce *Slightly reduce *Maintain as today *Slightly increase *Greatly increase

4. Do you think it is an acceptable behaviour of wolves if: a) they live in the wilderness far away from people; b) they can be observed close to where people live; c) they kill livestock; d) they kill cats and dogs; e) they threaten people?

*Totally unacceptable *More or less unacceptable *Neutral

*More or less acceptable *Perfectly acceptable

5. Which management actions do you think are acceptable when wolves behave as we asked in the previous question if: a) they live in the wilderness far away from people; b) they can be observed close to where people live; c) they kill livestock; d) they kill cats and dogs; e) they threaten people?

$*$ No action *Scare away *Capture and translocate *Shoot *Find the ways to coexist (damage prevention, people education, etc.) $*$ Do not know

6. Do you agree or disagree that it is dangerous to encounter a wolf in the wild?

*Agree *They can be dangerous if (please indicate)... * Disagree *Do not know

7. In your opinion, do wolves cause any damages to the farmers in Latvia?

*Yes, often *Yes, rarely *No *Do not know

8. Would the presence of wolves in your area directly cause you to lose money?

$*$ Yes, a lot *Yes, a little *No *Do not know

9. In your opinion what should be done with the management approaches for wolf?

*Maintain as today *Decrease hunting quota *Shorten hunting season *Prohibit hunting *Hunt only problem animals (livestock depredation) *Increase hunting quota *Prolong hunting season *Other actions (please indicate) *No opinion

10. Please indicate your attitude towards wolves.

*Extremely negative *Moderately negative *Slightly negative *Indifferent *Slightly positive *Moderately positive *Extremely positive

to be $54 \%$ female (Anonymous, 2017), and the difference between women proportions was also statistically significant $(p=0.001)$. The age structure of the SG was inclined towards younger age groups than the general population. Almost $46 \%$ of respondents were younger than 24 years, while in the general population this age group constituted around $12 \%$. The oldest age group was underrepresented in our school sample (9\% compared to $39 \%$ among the Latvian population). The proportion of respondents from urban areas was around $60 \%$, which was close to the $69 \%$ of the total population. The demographic structure of the sample may be biased to some extent; nevertheless, we believe that our study allows identification of general attitudes and of certain target groups important for conservation and management of large carnivores.

Compared to the school sample, the hunter sample was predominantly male $(94 \%)$ and older $\left(\chi^{2}=269.27,5 \mathrm{df}, p<\right.$ $0.001)$ - only around $2 \%$ of respondents were under the age of 24 and $23 \%$ over the age of 55. Proportion of urban inhabitants was $54 \%$ of respondents.

General attitude. Attitudes towards wolves were mostly neutral or positive both in the SG and HG, but the results were significantly different between groups $\left(\chi^{2}=43.47\right.$, $6 \mathrm{df}, p<0.001)$ with the HG being more positive. Positive attitudes were expressed by $31 \%$ of the SG and $45 \%$ of the HG. Conversely, $28 \%$ of the SG and $29 \%$ of the HG expressed negative attitudes, and $41 \%$ of the SG and $26 \%$ of the HG held neutral attitudes.

Older people had a slight tendency to be more negative, the correlation was statistically significant for the HG $(\mathrm{r}=$ $-0.12, p=0.011)$, but not for the SG $(\mathrm{r}=-0.3, p=0.432)$. When asked what should be done with wolf numbers, older people were more inclined to say that numbers should be decreased in both the SG $(\mathrm{r}=-0.28, p<0.001)$ and the HG $(\mathrm{r}=-0.12, p=0.011)$.

Both sexes in the SG were mostly neutral in their attitude towards wolves (men $-44 \%$, women $-39 \%$ ), but men were more positive towards wolves (34\%) than women (29\%), and women had a more negative attitude $(32 \%)$ than men (22\%). Attitude differences were statistically significant $\left(\chi^{2}=13.52,6 \mathrm{df}, p=0.036\right)$. Due to HG consisting predominantly of men, no comparison of sexes was done in this group.

Fear of wolves. When asked if wolves are dangerous, answers of both groups differed significantly $\left(\chi^{2}=301.69\right.$, $6 \mathrm{df}, p<0.001)$. Most of the SG agreed that wolves are dangerous $(67 \%)$ while only $23 \%$ of HG had this attitude. About $47 \%$ of the HG replied that wolves are not dangerous but only $10 \%$ of the SG had this view. $17 \%$ of the SG and $28 \%$ of the HG thought that wolves can be dangerous under specific circumstances. In the SG $71 \%$ of women considered wolves dangerous, compared to $58 \%$ for men. Differences were statistically significant $\left(\chi^{2}=12.44,3 \mathrm{df}, p=\right.$ 0.006).

Beliefs and tolerance of depredation and threats to humans. Both the SG and the HG deemed it acceptable if wolves live in forests far from human settlements $(76 \%$ and $77 \%$ respectively), and any impact on humans or their property is not tolerated. More than $80 \%$ of respondents in both groups said it was unacceptable if wolves attacked livestock, pets or humans. However acceptable measures of what to do differed significantly in the cases of attacks on livestock $\left(\chi^{2}=300.84,5 \mathrm{df}, p<0.001\right)$, attacks on pets $\left(\chi^{2}=266.54,5 \mathrm{df}, p<0.001\right)$ and attacks on humans $\left(\chi^{2}=\right.$ $210.39,5 \mathrm{df}, p<0.001$ ) between both groups. HG mostly deemed it necessary to harvest responsible animals 
(65-80\% depending on the kind of damage), while respondents of the SG supported non-lethal options (such as scaring animals away, relocating them or trying to find ways to coexist) more often (51\% in case of attacks on humans, $70-74 \%$ in case of attacks on livestock and pets). When asked if in their opinion wolves cause damage to farmers, answers of the SG and the HG were significantly different $\left(\chi^{2}=149.08,3 \mathrm{df}, p<0.001\right) .59 \%$ of the SG said that they cause damage but rarely, however $51 \%$ of the HG said they cause a lot of damage. In addition, $25 \%$ of the SG and $37 \%$ of the HG said that wolf presence in their vicinity causes them financial losses and answers were statistically significantly different between groups $\left(\chi^{2}=95.34,3 \mathrm{df}, p<\right.$ $0.001)$

Attitudes toward management actions. The questionnaire contained information about the current wolf management system and contained question regarding respondent opinion on the system. Group answers were significantly different $\left(\chi^{2}=431.12,9 \mathrm{df}, p<0.001\right) .30 \%$ of the SG and $55 \%$ of the HG answered that the current practice should be maintained. From other options the SG more often mentioned that harvest should be done only on sites of depredation $(17 \%)$ and that the hunting quota should be decreased (10\%). In the HG the second most popular option was an increase of the hunting quota $(36 \%)$ followed by the implementation of a longer hunting season (16\%) (Fig. 1). The HG more often than SG overestimated wolf numbers and they also more often answered that there are a lot of wolves in Latvia (64\%), while the SG most often said that there are enough wolves (54\%). When asked what should be done with wolf numbers, group answers differed significantly $\left(\chi^{2}=185.54,6 \mathrm{df}, p<0.001\right)$. The HG $(62 \%)$ more than the SG $(28 \%)$ said that numbers should be slightly or significantly decreased (Fig. 2).

Variables affecting attitude and opinions. Correlation of general attitude with opinions about what should be done with wolf numbers in Latvia was significant in both the SG $(\mathrm{r}=0.39, p<0.001)$ and $\mathrm{HG}(\mathrm{r}=0.40, p<0.001)$, suggesting that attitudes to some degree match with beliefs. The more negative the attitude, the more likely respondents were to answer that wolf numbers should be decreased. Ordinal regression confirmed this and showed how attitude toward wolves predicts people's opinions on what to do with the animals. For the SG, attitude explained $20 \%$ of variance in the opinions. For the HG it explained $21 \%$ of variance in opinions. Both regressions were statistically significant $(p<$ 0.001 ). If the attitude becomes more positive, opinions will lean more towards keeping animal numbers as they are.

Similar results were observed with attitude and perceived financial losses. The more losses respondents perceived the more negative their attitude tended to be both in the SG ( $\mathrm{r}=$ $0.09, p=0.026)$ and in the HG $(\mathrm{r}=0.24, p<0.001)$, with this correlation being significantly stronger in the $\mathrm{HG}(\mathrm{z}=$ $-2.5, p=0.0062)$. Opinion on financial losses was not significantly correlated with the SG opinion about what should be done with wolf numbers $(r=0.08, p=0.063)$, however the HG was significantly more inclined towards decreasing

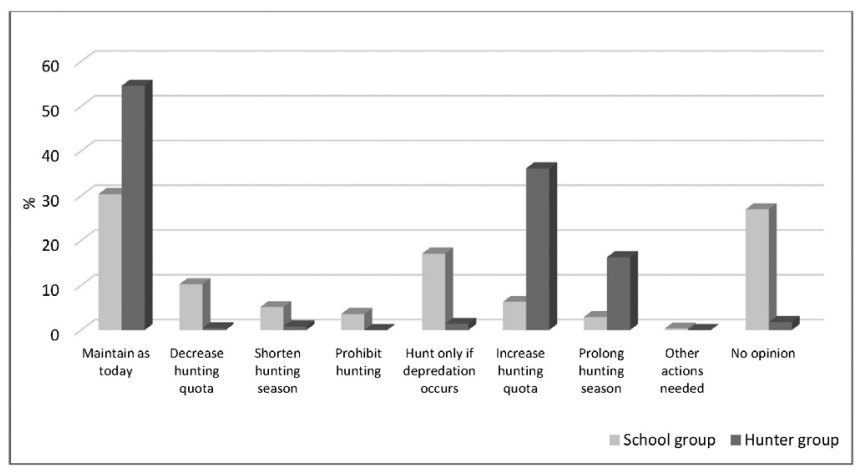

Fig. 1. The opinion on current wolf population management in Latvia, expressed by the respondents in a survey in 2017

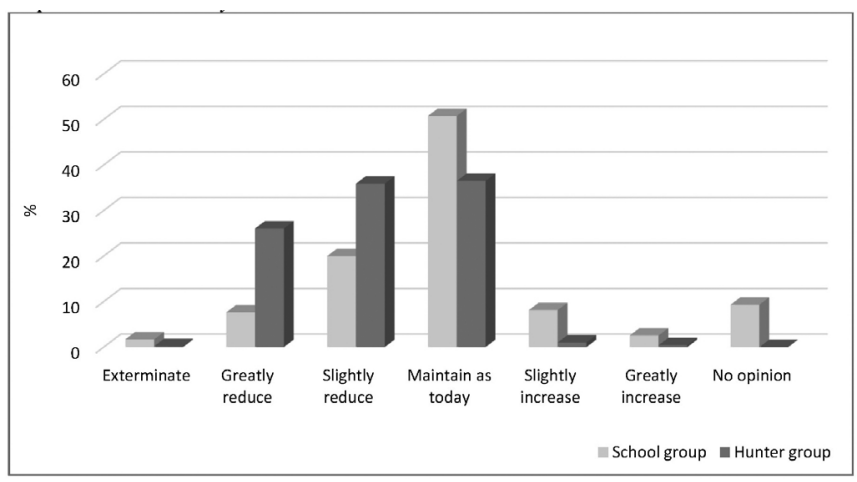

Fig. 2. The opinion on what should be done with current wolf numbers in Latvia, expressed by the respondents in a survey in 2017

wolf numbers if they perceived that wolf presence caused them financial losses $(r=0.27, p<0.001)$.

A Kruskal Wallis test showed that attitude was more negative if respondents perceived wolves as dangerous, in both the SG $\left(\chi^{2}=13.7,3 \mathrm{df}, p=0.003\right)$ and the HG $\left(\chi^{2}=55.34\right.$, $3 \mathrm{df}, p<0.001)$. Similarly, respondents in both groups $\left(\mathrm{SG}-\chi^{2}=8.67,3 \mathrm{df}, \mathrm{p}=0.034\right.$ and $\mathrm{HG}-\chi^{2}=18.38,3 \mathrm{df}$, $p<0.001$ ) were more inclined to decrease wolf numbers if they perceived them as dangerous.

The correlation for attitude and belief that wolves cause damages to livestock showed a significant relationship in both groups (school $(\mathrm{r}=0.23, p<0.001)$ and hunter $(\mathrm{r}=$ $0.26, p<0.001)$ ), and this belief tended to be related to a more negative attitude. Also, respondents who believed that wolves cause damage were more inclined to decrease wolf numbers in Latvia $(\mathrm{r}=0.30, p<0.001$ for SG and $\mathrm{r}=$ $0.34, p<0.001$ for $\mathrm{HG})$.

The Cramer's V test showed a strong association $\left(\mathrm{V}_{3}=0.32\right.$ in $\mathrm{SG}$ and $\mathrm{V}_{2}=0.53$ in $\mathrm{HG}$ ) between perceived numbers of wolves and opinions on what should be done with the animals. If respondents thought that there are a lot of animals, they were more inclined to decrease their numbers.

Using a multi-factor nominal regression analyses, we explored how three variables (perceived number of wolves, perceived attacks on livestock and dangerousness of wolves) affected attitudes towards wolves. For the SG these three variables explained only $23 \%$ of the total variance in 
attitude, with the most important being perceived livestock attacks and dangerousness. The regression model was statistically significant $(p<0.001)$. For the HG these three variables explained $29 \%$ of the variance in attitude. The regression model was also statistically significant $(p<0.001)$. To some degree attitude towards wolves can be predicted by peoples' opinions of wolf numbers in Latvia, perceived dangerousness, and the belief that they cause a lot of damage.

\section{DISCUSSION}

Group differences. In general the Latvian public had a neutral or positive attitude toward wolves and was mostly satisfied with the current situation and current management system. Even if they perceived wolves as dangerous or believed that they cause damage to farmers, they would mostly like to keep wolf numbers as they are and would choose non-lethal methods when dealing with problem situations. Preference for non-lethal methods when dealing with carnivores was also found in other studies (Bruskotter et al., 2009; Glikman et al., 2011; Sponarski et al., 2015; Engel et al., 2017). Hunters on the other hand expressed a more positive attitude toward wolves, as was also observed in a study in Croatia (Bath and Majic, 2000). However they were still more likely to say that wolves cause financial losses to them and damage to farmers. Hunters more often would like to prolong the hunting season or raise the hunting quota and would like to decrease wolf numbers in Latvia. Attitude towards the current management system might be influenced by respondent's opinions of how many wolves there are in Latvia, as hunters often overestimated wolf numbers.

Older people usually hold more negative attitudes towards predators (Bath and Majic, 2000; Ericsson and Heberlein, 2003). However, we observed only a slight tendency for older people to have a more negative attitude in the HG and no significant differences among age groups in the SG attitude (that could be due to the under-represented older age group in SG). Nevertheless, a preference to decrease wolf numbers was more pronounced in older age groups, showing that generation differences exist among the respondents from both groups. Younger people nowadays tend to place more value on wildlife conservation than in traditional uses of natural resources (Vaske and Donnelly, 1999), which could explain why their attitude and actions regarding wolves would also be more positive.

Women had a less positive attitude toward wolves than men in our study, and also showed greater fear of wolves. Differences between sexes have also been observed in other studies (Bath, 1989; Ericsson and Heberlein, 2003; Røskaft et al., 2003; Kleiven et al., 2004; Bath et al., 2008). This suggests that an education campaign targeting women could be useful to change their attitude to being more positive (Bath et al., 2008).

Many respondents in the SG $(67 \%)$ said that wolves are dangerous, showing that people fear these animals. In addi- tion, respondents of the SG who considered that wolves are dangerous only under certain conditions mostly indicated conditions that are not usually a reason for wolf attack, such as lack of food (that is not an issue for wolves in Latvia) or protection of cubs. Respondents in the HG had better knowledge of those conditions and mostly mentioned rabies, other illness or injury. Educational information could be useful on the real dangerousness of wolves and situations when wolf attacks may occur.

Other studies have found that many people hold a neutral attitude toward wolves (Ericsson and Heberlein, 2003; Majić and Bath, 2010). In our case this was $41 \%$ in SG and $26 \%$ in HG. This can be considered positive in the way that neutral attitudes mean less conflict (Majić and Bath, 2010). These people are an important part to consider when organising educational activities, as they can be swayed both ways by strongly publicised events or opinions (Ericsson and Heberlein, 2003).

Predictors of attitude. Tendencies were observed that negative attitudes were correlated with beliefs that there are many wolves in Latvia, and that wolves are dangerous and cause damage to farmers and financial losses to people. Also, a more negative attitude, was related to respondent willingness to decrease wolf numbers. In the SG, perceived depredation and dangerousness were the most significant factors predicting negative attitudes. Fear is an important factor influencing attitude and should always be considered with large carnivores, as has been found in other studies (Linnell et al., 2002; Røskaft et al., 2003; Bath et al., 2008). In addition, when respondents perceived that wolves impact their property and belongings (livestock), their feelings were more negative. Similar results were found in a study on coyotes in Newfoundland (Frank et al., 2016). In the HG the perceived number of animals was an important part of predicting attitudes toward wolves. Opinions that there are a lot of wolves was correlated with a more negative attitude. HG overestimated wolf numbers in the country, which might have contributed to their negative attitude. Judging by answers in questionnaires, their attitude could become more positive if they could hunt more or if the number of wolves in Latvia would be low. Providing hunters with information on actual wolf numbers appears to be necessary.

To some extent, attitude predicted opinions on actions regarding wolf numbers in both respondent groups, where a more negative attitude was correlated with willingness to decrease wolf numbers. This is especially important regarding hunters, and improvement of their attitude would be significant, as they are the ones that actually influence wolf numbers and are an important interest group, as certain changes to the wolf management system are in their interests.

Changing attitudes over time. As our research was in a way a repetition of a study done 16 years ago (Andersone and Ozoliņ̌s, 2004), this gives us an opportunity to compare data and to see if attitudes have changed over time. As found in other studies (Williams et al., 2002) public attitude 
can be rather stable over years. This was also found in our study, in that public perception had not changed dramatically over the years. Attitude towards wolves was still mostly neutral or positive. As in the previous study, today people mostly think that wolf numbers are sufficient and they support wolf control. Similar to our earlier findings, older people were more inclined to decrease wolf numbers than younger people. Slightly more people than previously thought that wolves were dangerous. No considerable differences were found in $\mathrm{HG}$, however previously hunters mostly said that wolf numbers were sufficient, whereas nowadays they think that there are many wolves in Latvia and they mostly expressed the opinion that more wolves should be hunted.

The above can be considered as a rather favourable situation for wolf conservation and management in Latvia, in that increasing wolf numbers during these years has not changed inhabitants' attitudes towards being predominantly negative and that the current management system is seen as mostly acceptable. One explanation could be that younger people from the earlier survey retained their positive or neutral attitudes when they entered the next age groups. Regarding hunters, their attitude seems to be positive as long as they can hunt wolves.

Implications to management and conservation policy. The aim of the renewed Action Plan for Grey Wolf Canis lupus Conservation and Management is "to maintain a favourable status for the wolf population in Latvia for an unlimited period of time (...), while ensuring the presence of wolves as a united and functional component of the wildlife environment in man-made and managed landscapes..." (Ozolinšs et al., 2017). To ensure this, a positive or at least neutral attitude toward wolves would be necessary.

Our survey showed that overall public perception and attitudes are favourable for the wolf conservation and management system in Latvia, as most respondents showed no interest in noticeable changes of the current situation. Attention should be paid to some opposing opinions considering specific questions; however, those could be mitigated through educational activities and communication. The main sources of information open to people should be used as a medium to deliver such information.

Regarding people with neutral attitudes, attention should be paid to the information that is provided to society. The Latvian press mostly writes about wolves in relation to hunting or depredation, thus forming society's awareness of wolves. The depredation cases are usually strongly reported in the press, making it appear that this problem is widespread and much larger than it actually is. It would likely be more challenging to change the attitude of people with negative opinions. However, it would be rather easy to maintain a neutral attitude or even change it to a more positive one with informational activities on actual depredation rates and the lack of use of preventive measures on the farmers' side. Nevertheless, it should be kept in mind that it may be the case that people with a neutral attitude mostly do not care enough about the given issue and thus may not be interested in educational campaigns (Ericsson and Heberlein, 2003).

Although hunters expressed rather positive attitudes toward wolves, their willingness to hunt more and to decrease wolf numbers should be kept in mind and monitored in the future, as wolves already are under intense hunting pressure (Ozoliņš et al., 2017). Educational information could be supplied through hunter magazines about the real situation of the wolf population and animal numbers in the country. In addition, the situation with the depredation amount should be clarified so as to minimise negative attitudes in this regard.

Reasons for negative attitudes, although only partly established in this study, should be considered. Informational activities on the actual situation with the wolf population in Latvia and improvement of general knowledge on wolves could be helpful. As the selected variables predicted only $23-29 \%$ of attitude, other variables affecting attitude could be explored in future studies.

This study suggests that the surveys of public attitudes and opinions should be continued within the country and with various interest groups. In future studies farmers should be included as one of the relevant interest groups regarding wolf management and conservation. Also, nature and animal protection organisations should be considered, as they have become more common in Latvia.

\section{ACKNOWLEDGMENTS}

We are grateful to Dr. Alistair J. Bath for his help in study design. We thank the Latvian Environmental Protection Fund for financial support of this research (project no. 1-20/117). We are also grateful to school teachers, hunter organisations and magazine Medības. Makškerēšana. Daba for distributing questionnaires and to all the respondents who shared with us their insights and time.

\section{REFERENCES}

Andersone, Ž., Ozoliņ̌s, J. (2004). Public perception of carnivores in Latvia. Ursus, 15 (2), 181-187.

Anonymous (2017). Central Statistical Bureau databases. Population: Number and change.

http://data1.csb.gov.lv/pxweb/en/iedz/iedz__iedzskaits__ikgad/ (accessed 9 August 2020).

Bath, A. J. (1987). Attitudes of Various Interest Groups in Wyoming Toward Wolf Reintroduction in Yellowstone National Park. MA Thesis, University of Wyoming, Laramie. 124 pp.

Bath, A. J. (1989). The public and wolf reintroduction in Yellowstone National Park. Soc. Nat. Res., 2, 297-306.

Bath, A. J., Buchanan, T. (1989). Attitudes of interest groups in Wyoming towards wolf restoration in Yellowstone National Park. Wildl. Soc. Bull., 17, 519-525.

Bath, A. J., Majic, A. (2000). Human dimensions in wolf management in Croatia: Understanding attitudes and beliefs of residents in Gorski Kotar, Lika and Dalmatia toward wolves and wolf. Report. Available at: https://lciepub.nina.no/pdf/635011364836702351_Bath\%20LCIE\%20Cr oatian\%20attitudes.pdf (accessed 6 August 2020). 
Bath, A., Olszanska, A., Okarma, H. (2008). From a human dimensions perspective, the unknown large carnivore: Public attitudes toward Eurasian Lynx in Poland. Hum. Dimensions Wildl., 13, 31-46.

Blanco, J. C., Reig, S., de la Cuesta, L. (1992). Distribution, status and conservation problems of the wolf Canis lupus in Spain. Biol. Conserv., 60 (2), 73-80.

Boitani, L. et al. (2015). Key actions for Large Carnivore populations in Europe. Institute of Applied Ecology (Rome, Italy). Report to DG Environment, European Commission, Bruxelles. Contract No. 07.0307/2013/ 654446/SER/B3. Available at: https://ec.europa.eu/environment/nature/conservation/species/carnivores/pdf/key_actions_large_carnivores_2015.pdf (accessed 6 August 2020).

Bruskotter, J. T., Vaske, J. J., Schmidt, R. H. (2009). Social and cognitive correlates of Utah residents' acceptance of the lethal control of wolves. Hum. Dimensions Wildl., 14, 119-132.

Engel, M. T., Vaske, J. J., Bath, A. J., Marchini, S. (2017). Attitudes toward jaguars and pumas and the acceptability of killing big cats in the Brazilian Atlantic Forest: An application of the Potential for Conflict Index 2. Ambio, 46 (5), 604-612.

Ericsson, G., Heberlein, T. A. (2003). Attitudes of hunters, locals and general public in Sweden now that wolves are back. Biol. Conserv., 111, 149-159.

Ericsson, G., Heberlein, T. A., Karlosson, J., Bjärvall, A., Lundvall, A. (2004). Support for hunting as a means of wolf Canis lupus population control in Sweden. Wildl. Biol., 10, 269-276.

Frank, B., Glikman, J. A., Sutherland, M., Bath, A. J. (2016). Predictors of extreme negative feelings toward coyote in Newfoundland. Hum. Dimensions Wildl., 21 (4), 297-310.

Fritts, S. H., Stephenson, R. O., Hayes, R. D., Boitani, L. (2003). Wolves and humans. In: Mech, L. D., Boitani, L. (eds.) Wolves: Behavior, Ecology and Conservation. The University of Chicago Press, Chicago, IL, pp. 289-316.

Fulton, D. C., Manfredo, M. J., Lipscomb, J. (1996). Wildlife value orientations: A conceptual and measurement approach. Hum. Dimension Wildl., 1, 24-47.

Glikman, J. A., Bath, J. A., Vaske, J. J. (2010). Segmenting normative beliefs regarding wolf management in Central Italy. Hum. Dimensions Wildl., 15, 347-358.

Glikman, J. A., Vaske, J. J., Bath, A. J., Ciucci, P., Boitani, L. (2011). Residents' support for wolf and bear conservation: The moderating influence of knowledge. Eur. J. Wildl. Res., 58 (1), 295-302.

Kawata, Y., Ozolinš, J. Andersone-Lilley, Z. (2008). An analysis of the game animal population data from Latvia. Baltic Forestry, 14 (1), 75-86.
Kellert, S. R. (1987). The public and the timber wolf in Minnesota. Anthrozoös, 1 (2), 100-109.

Kleiven, J., Bjerke, T., Kaltenborn, B. P. (2004). Factors influencing the social acceptability of large carnivore behaviours. Biodivers. Conserv., 13, 1647-1658.

Linnell, J. D. C., Andersen, R., Andersone, Balciauskas, L., (2002). The Fear of Wolves: A Review of Wolf Attacks on Humans. Norwegian Institute of Nature Research, Trondheim, Oppdragsmelding. 731 pp.

Majić, A., Bath, A. J. (2010). Changes in attitudes toward wolves in Croatia. Biol. Conserv., 143, 255-260.

Manfredo, M. (2008). Who Cares About Wildlife? Social Science Concepts for Exploring Human-Wildlife Relationships and Conservation Issues. Springer, New York. 228 pp.

Ozoliņ̌s, J., Andersone, Ž. (2002). Management Plan for Wolf(Canis lupus) in Latvia. LSFRI Silava, Salaspils. 40 pp.

Ozoliņš, J., Žunna, A., Ornicāns, A., Done, G., Stepanova, A., Pilāte, D., Šuba, J., Lūkins, M., Howlett, S. J., Bagrade, G. (2017). Action Plan for grey wolf Canis lupus Conservation and Management. LSFRI Silava, Salaspils. 80 pp.

Røskaft, E., Bjerke, T., Kaltenborn, B., Linnell, J. D. C., Andersen, R. (2003). Patterns of self-reported fear towards large carnivores among the Norwegian public. Evol. Hum. Behav., 24, 184-198.

Røskaft, E., Händel, B., Bjerke, T., Kaltenborn, B. P. (2007). Human attitudes towards large carnivores in Norway. Wildl. Biol., 13 (2),172-185.

Sponarski, C. C., Semeniuk, C., Glikman, J. A., Bath, A. J., Musiani, M. (2013). Heterogeneity among rural resident attitudes toward wolves. Hum. Dimensions Wildl., 18, 239-248.

Sponarski, C. C., Vaske, J. J., Bath, A. J. (2015). Differences in management action acceptability for coyotes in a national park. Wildlife Soc. Bull., 9999, $1-9$.

Vaske, J. J., Donnelly, M. P. (1999). A value-attitude-behavior model predicting wildland voting intentions. Soc. Nat. Res., 12, 523-537.

Williams, C. K., Ericsson, G., Heberlein, T. A. (2002). A quantitative summary of attitudes toward wolves and their reintroduction $(1972-2000)$. Wildlife Soc. Bull., 30 (2), 575-584.

Zeiler, H., Zedrosser, A., Bath, A. (1999). Attitudes of Austrian hunters and Vienna residents toward bear and lynx in Austria. Ursus, 11, 193-200.

Received 18 February 2019

Accepted in the final form 17 September 2019

\section{SABIEDRĪBAS UN MEDNIEKU ATTIEKSME PRET VILKIEM LATVIJĀ, TO PAREDZOŠIE FAKTORI UN IZMAIN̦AS LAIKA GAITĀ}

Tika veikta aptauja, lai noskaidrotu sabiedrības un mednieku attieksmi pret vilkiem (Canis lupus) Latvijā. Mūsu mērkis bija saprast attieksmes iemeslus un salīdzināt mūsu rezultātus ar Latvijā agrāk veiktā pētījuma rezultātiem. Aptaujas anketas tika izplatītas skolās un mednieku organizācijās. Lielākoties gan sabiedrības kopumā, gan mednieku attieksme bija neitrāla vai pozitīva. Gados vecākiem cilvēkiem un sievietēm bija mazāk pozitīva attieksme. Respondenti ar mazāk pozitīvu attieksmi biežāk teica, ka vilku skaits valstī būtu jāsamazina. Būtiskas saistības tika konstatētas starp attieksmi, pieņēmumiem, ka vilki nodara postījumus un finansiālus zaudējumus, un uzskatiem, kas būtu darāms ar vilku skaitu. Tika noteikti trīs attieksmi paredzošie faktori. 